\title{
Vase life consequences of natural and chemical treatments in foxtail lily (Eremurus spectabilis), as a specialty cut flowers
}

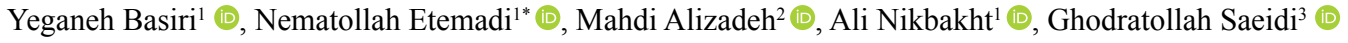 \\ ${ }^{1}$ Department of Horticulture, College of Agriculture, Isfahan University of Technology, 8415683111, Isfahan, Iran \\ ${ }^{2}$ Department of Horticulture, Faculty of Plant Production, Gorgan University of Agricultural Sciences and Natural Resources, Gorgan, Iran \\ ${ }^{3}$ Department of Agronomy and Plant Breeding, College of Agriculture, Isfahan University of Technology, 8415683111, Isfahan, Iran
}

\begin{abstract}
Eremurus spectabilis is a new, commercially valuable specialty cut flower, but little is known about the applicable treatments to extend the vase-life and maintaining the ornamental quality of this flower. Therefore, the present study was aimed at investigating the impacts of nano-silver, essential oils, and chemical treatments on keeping ornamental quality and vase-life of cut inflorescences of Foxtail lily. The cut inflorescences were placed in different vase solutions containing salicylic acid (100 and $\left.200 \mathrm{mg} \mathrm{L}^{-1}\right)$, methyl jasmonate $\left(25\right.$ and $\left.50 \mathrm{mg} \mathrm{L}^{-1}\right)$, silver thiosulfate $(0.1 \mathrm{mM})$ plus isothiazolinone $\left(0.001\right.$ and $\left.0.005 \mathrm{~mL} \mathrm{~L}^{-1}\right)$, nano-silver $(5,10$, and $\left.15 \mathrm{mg} \mathrm{L}^{-1}\right)$, thymol $\left(75\right.$ and $\left.120 \mathrm{mg} \mathrm{L}^{-1}\right)$, and menthol $\left(75\right.$ and $\left.120 \mathrm{mg} \mathrm{L}^{-1}\right)$, which were applied as continuous and pulsing methods. According to the results, all treatments considerably improved the post-harvest performance of Foxtail lily cut flowers. Although there were no significant differences among nano-silver (NS) treatments, the cut inflorescences kept in vase solution containing 10 $\mathrm{mg} \mathrm{L}^{-1}$ of NS exhibited the longest vase life ( $\sim 14$ days) and the best ornamental quality. Nano-silver treatment followed by silverthiosulfate significantly improved solution uptake by flowering inflorescences, thereby delaying the water balance loss and keeping relative fresh weight. Furthermore, $50 \mathrm{mg} \mathrm{L} \mathrm{g}^{-1}$ methyl jasmonate- and $75 \mathrm{mg} \mathrm{L}^{-1}$ menthol-treated cut inflorescences exhibited significantly higher vase-life longevity by $\sim 6$ and 4 days, total soluble solutes by $28.38 \%$ and $19.12 \%$, and solution uptake rate by $76.46 \%$ and $140.6 \%$, respectively, as compared to control. Overall, $10 \mathrm{mg} \mathrm{L}^{-1} \mathrm{NS}$ can be recommended as a commercial preservative solution to delay flower senescence and improve the vase life and keeping the quality of foxtail cut inflorescence.

Keywords: Eremurus spectabilis, ornamental quality, postharvest treatments, vase solution.
\end{abstract}

\section{Resumo}

Consequências de tratamentos naturais e químicos na vida de um vaso em Foxtail Lily Eremurus spectabilis), como flores de corte especiais

Eremurus spectabilis é uma nova flor de corte com valor comercial, mas pouco se sabe sobre os tratamentos aplicáveis para prolongar a vida de vaso e manter a qualidade ornamental desta flor. Portanto, o presente estudo teve como objetivo investigar os impactos da nanoprata, dos óleos essenciais e dos tratamentos químicos na manutenção da qualidade ornamental e da vida de vaso de inflorescências cortadas de eremurus ou lírio-rabo-de raposa. As inflorescências cortadas foram submetidas a diferentes soluções de vaso contendo ácido salicílico $\left(100\right.$ e $\left.200 \mathrm{mg} \mathrm{L}^{-1}\right)$, jasmonato de metila $\left(25\right.$ e $\left.50 \mathrm{mg} \mathrm{L}^{-1}\right)$, tiossulfato de prata $(0,1$ $\mathrm{mM})$ mais isotiazolinona $\left(0,001\right.$ e $\left.0,005 \mathrm{ml} \mathrm{L}^{-1}\right)$, nanoprata $\left(5,10\right.$ e $\left.15 \mathrm{mg} \mathrm{L}^{-1}\right)$, timol $\left(75\right.$ e $\left.120 \mathrm{mg} \mathrm{L}^{-1}\right)$ e mentol $(75$ e $120 \mathrm{mg}$ $\mathrm{L}^{-1}$ ), os quais foram aplicados nos métodos contínuo e pulsado. De acordo com os resultados, todos os tratamentos melhoraram consideravelmente o desempenho pós-colheita de flores de corte de lírio rabo-de-raposa. Embora não tenha havido diferenças significativas entre os tratamentos com nanoprata (NS), as inflorescências cortadas mantidas em solução de vaso contendo 10 $\mathrm{mg} \mathrm{L}^{-1}$ de NS exibiram a maior vida de vaso ( $\sim 14$ dias) e a melhor qualidade ornamental. O tratamento com nanoprata seguido por tiossulfato de prata melhorou significativamente a absorção da solução pelas inflorescências em flor, atrasando assim a perda do equilíbrio de água e mantendo o peso fresco relativo. Além disso, as inflorescências cortadas tratadas com $50 \mathrm{mg} \mathrm{L}^{-1}$ de metil jasmonato e $75 \mathrm{mg} \mathrm{L}^{-1}$ de mentol exibiram longevidade de vaso significativamente maior em $\sim 6$ e 4 dias, solutos solúveis totais em $28,38 \%$ e $19,12 \%$ e taxa de absorção de solução em 76,46\% e 140,6\%, respectivamente, em comparação com o controle. No geral, $10 \mathrm{mg} \mathrm{L} \mathrm{L}^{-1} \mathrm{NS}$ pode ser recomendado como uma solução conservante comercial para atrasar a senescência da flor e melhorar a vida de vaso e manter a qualidade da inflorescência de corte de lírio rabo-de-raposa.

Palavras-chave: Eremurus spectabilis, qualidade ornamental, solução de vaso, tratamentos pós-colheita.

*Corresponding author: etemadin@cc.iut.ac.ir 


\section{Introduction}

Desert candle or foxtail lily (Eremurus spectabilis), an ornamental plant of the Asphodelaceae family, is one of the indigenous plants of temperate regions, in which spike-type inflorescences (Figure 1C) are found in several colors (Schiappacasse et al., 2013; Ahmad et al., 2014). This plant is well recognized for its starfish-like root system (Figure 1B) and the long and narrow leaves (Figure 1A).
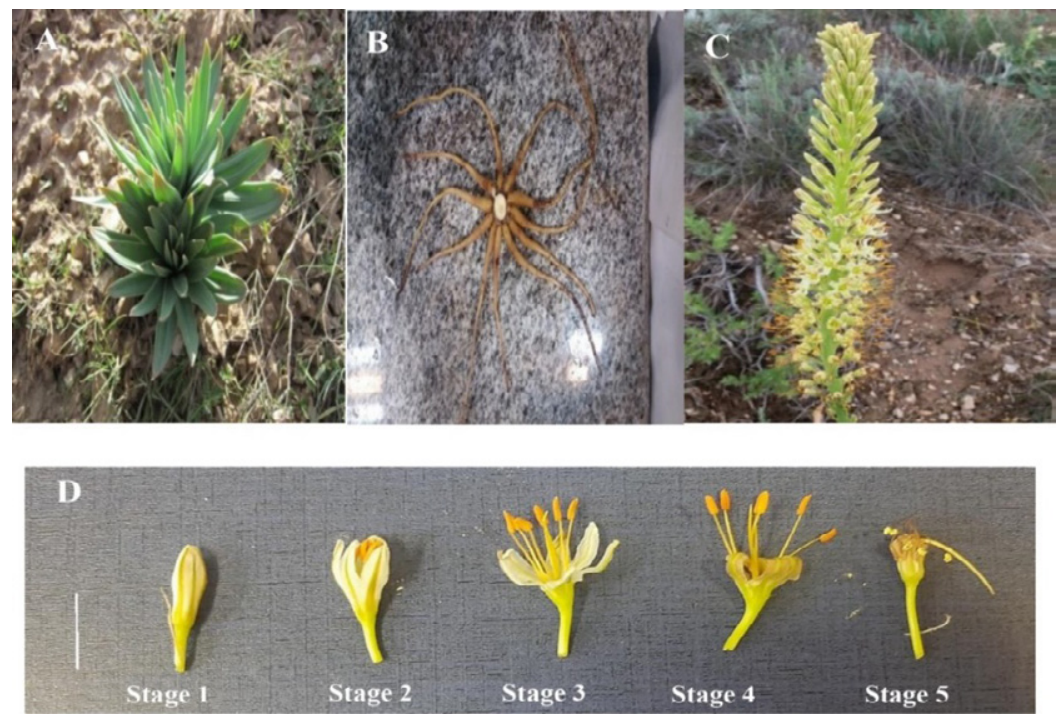

Figure 1. The structure of aerial (A), root system (B), and the inflorescence (C) of Eremurus spectabilis. The development stage of florets in the inflorescence based on their deterioration and opening status $[\mathrm{Bare}=1 \mathrm{~cm}](\mathrm{D})$.

Eremurus genus has about 40 species and several varieties and hybrids which widespread in western and central Asia countries, including in Iran, western Pakistan, Turkey, Lebanon, Syria, and Caucasus (Schiappacasse et al., 2013). Iran is considered to be one of the main regions for growing seven species of Eremurus (Hadizadeh et al., 2020), with four species native to Golestan province (north of Iran). Among them, E. spectabilis is the most abundant species as a spring ornamental geophyte with shiny yellow to white flowers that can be cultivated in the outdoor conditions of this area.

The vase longevity is one of the most key parameters for the evaluation of the quality of cut flowers. Short vase life, early senescence and wilting are considered as the main obstacles for commercializing cut flowers (Mansouri, 2012). From the physiological point, short vase life and early senescence are mainly attributing to blockage of xylem vessels, resulting in water stress in different tissues of cut flower. This vessel blockage can be induced by the formation of air bubbles in the vascular system (Van Doorn, 2013), the rapid proliferation of microorganisms, and the plant response to wound cutting (Van Doorn, 2013; Li et al., 2017). Several post-harvest treatments have been recommended for enhancing water uptake and increasing the vase-life of cut flowers, including the application of germicide and chemical preservatives (Akhtar, et al., 2021). These preservatives must include particularly multi components, germicides and sugar (Akhtar, et al., 2021).

Suppression of microbial proliferation is a major key factor for enhancing the longevity and quality of cut flowers (Naing and Kim, 2020). Chlorine, 8- hydroxyquinoline sulfate (8-HQS), and hydrogen gas have been widely used to improve the vase life of cut flowers in the floral industry (Van Doorn, 2013; Wang et al., 2020). However, most of these commercial agents still have some disadvantages, such as no ideal effect, poor stability, environmental pollution and toxicity ( $\mathrm{Li}$ et al., 2017). In this context, nanosilver (NS), due to strong antibacterial activity and wide activity spectrum and safety, recently gained attention as a promising antimicrobial agent (Li et al., 2017; Langroudi et al., 2020).

The positive effects of nano-silver have been found for reducing ethylene production and improving the vase life longevity of cut flowers (Naing and Kim, 2020). Furthermore, NS particles treatment significantly suppressed the expression levels of ACS1 and ACO1 genes of ethylene biosynthesis pathway as well as petal senescence-related gene $(C P 1)$, resulting in significantly extended vase life of carnation flower (Naing et al., 2017; Park et al., 2017; Naing et al., 2021). Furthermore, the use of non-chemical alternatives such as plant essential oils recently has become a common practice in the postharvest pathogen control due to environment-friendly and antimicrobial characteristics (Akhtar et al., 2021).

Vase life of Gerbera Jamesonii Cv. 'Dune' Improved by addition of $100 \mathrm{mg} \mathrm{L}^{-1}$ essential oil (Solgi et al., 2009). In carnation flower application of Lavender or Thyme essential oil to the vase solution increased the vase life compared to the control (Kazemi and Ameri, 2012). However, the effectiveness of the above natural and chemical compounds may be varied between different cut flower species and need to be optimized in a specific cut flower. 
In recent years, there is a growing demand for Foxtail lily cut inflorescences in the trade market. The evaluation of effective post-harvest strategies for extending the vaselife of this cut flower has hardly been studied (Ahmad et al., 2014). However, there is limited data on the influence of various natural and chemical agents for prolong the vase life of this cut flower. Therefore, the objective of the present study was to evaluate and compare the effect of several post-harvest applications of anti-microbial as well as anti-ethylene agents on maintaining quality and the prolong vase life of cut Foxtail lily inflorescences.

\section{Materials and Methods}

\section{Plant materials}

The inflorescences of E. spectabilis Clade II (Hadizadeh et al., 2020), an endemic species of Foxtail lily in northern Iran, were studied in this experiment. Foxtail lily inflorescences were kindly purchased from Golestan National Park [Location: Iran. Latitude: $37^{\circ}$ 32' 49.8" (37.5472 $)$ North. Longitude: 56 ${ }^{\circ} 23$ ' 22.4" $\left(56.3896^{\circ}\right)$ East. Elevation: 1,150 meters (3,773 feet)] and immediately brought to the laboratory of the Faculty of Plant Production, Gorgan University of Agricultural Sciences and Natural Resources. The harvested inflorescences were bunched and submerged in the water during transfer to prevent dehydration. In the laboratory, uniform inflorescences free of any visual defects were choices for use in this study. Before treatment, the distal end of spikes was re-cut to the length of $65 \mathrm{~cm}$ under deionized water to eliminate intra-vessels and end-ofstem bubbles.

\section{Treatments}

The experiment was carried out as a CRD with 14 treatments and 3 replications, with 3 inflorescences in each replication. The postharvest treatments consisted of salicylic acid (SA) at 100 and $200 \mathrm{mg} \mathrm{L}^{-1}$ (pulse treatment), methyl jasmonate (MeJA) at 25 and $50 \mathrm{mg} \mathrm{L}^{-1}$ (pulse treatment), 1 $\mathrm{mM}$ of silver thiosulfate (STS) + isothiazolinone (ITZ) at 1 and $5 \mu \mathrm{L}^{-1}$ (pulse treatment), nano-silver (NS) at 5, 10 and $15 \mathrm{mg} \mathrm{L}^{-1}$ (in preservative solutions), thymol at 75 and $120 \mathrm{mg} \mathrm{L}^{-1}$ (in preservative solutions), and menthol at 75 and $120 \mathrm{mg} \mathrm{L}^{-1}$ (in preservative solutions). The chemical materials, along with their purity used in this study, are listed in Table 1.

Table 1. List of chemical material used in this study

\begin{tabular}{|c|c|c|c|}
\hline Chemical material & Chemical/Hill formula & Purity (\%) & Company \\
\hline Thymol & $\mathrm{C}_{27} \mathrm{H}_{30} \mathrm{O}_{5} \mathrm{~S}$ & Merck \\
\hline$(-)$-Menthol & $\mathrm{C}_{10} \mathrm{H}_{20} \mathrm{O}$ & 99.0 & Merck \\
\hline Nanosilver & $\mathrm{Ag}$ & 99.99 & Fine Nano \\
\hline Salicylic acid & $\mathrm{HOC}_{6} \mathrm{H}_{4} \mathrm{COOH}$ & 99.5 & Merck \\
\hline Methyl jasmonate & $(\mathrm{O}=) \mathrm{C} 5 \mathrm{H} 6(\mathrm{CH} 2 \mathrm{CH}=\mathrm{CHC} 2 \mathrm{H} 5) \mathrm{CH} 2 \mathrm{CO} 2 \mathrm{CH} 3$ & 98.0 & Sigma \\
\hline Silver sulfate & $\mathrm{Ag}_{2} \mathrm{SO}_{4}$ & 98.5 & Merck \\
\hline
\end{tabular}

All pulse treatments were applied for $24 \mathrm{~h}$ at $25{ }^{\circ} \mathrm{C}$ and control inflorescences were pulsed in deionized water. The inflorescences were placed in vase containing 500 $\mathrm{mL}$ solution. Sucrose at $5 \%$ was added to all preservative solutions. The treatment influences were investigated by maintaining the cut inflorescences in the laboratory at a relative humidity of $60 \pm 5^{\circ} \mathrm{C}$, the temperature of $20 \pm 2{ }^{\circ} \mathrm{C}$, and light intensity $12 \mu \mathrm{mol} \mathrm{m}{ }^{-2} \mathrm{~s}^{-1}$ with a photoperiod of 12 $\mathrm{h}$ provided by cool-white fluorescent lamps. The harvest day was considered day zero.

\section{Vase performance assessments}

The vase life and the 'ornamental quality', of cut foxtail lily inflorescences were evaluated on perceived floret opening stage, gravitropism, and petal rolling, necrosis, browning, or wilting. The deterioration and opening status of florets was classed in flower bud (stage 1), half-open (stage 2), full open (stage 3), beginning of wilting (stage 4), and full wilting (stage 5) [Figure 1D]. The visual rating of ornamental quality was carried out based on a scale from 1 to 10 , where: $10=100 \%$ of florets were in stage 1 to 3 and free of any petal rolling and discoloration and $1=90-100 \%$ florets were in stage 4 and 5 with rolled and discolored petals. The vase life of an inflorescence was judged as ended when either ornamental quality was $<5$ or the cut inflorescence at an angle greater than $70^{\circ}$.

\section{Measurement of water relations}

The preservative solution weight, without and with cut inflorescence, was recorded every three days during the vase-life evaluation period. The uptake of water from the inflorescence was measured using the formula and expressed in gram/inflorescence for that period: Water uptake $=\mathrm{PS}_{\mathrm{d}-3}{ }^{-}$ $\mathrm{PS}_{\mathrm{d}}$; where $\mathrm{PS}_{\mathrm{d}}$ is the weight of the preservative solution (in g) at $\mathrm{d}=$ day $3,6,9$, and $\mathrm{PS}_{\mathrm{d}-3}$ is the weight of the preservative solution ( $\mathrm{g}$ ) on the 3 previous days.

The loss of water from the cut inflorescence was obtained by the difference between combined weights of the cut inflorescence and preservative solution during the evaluation period, and it is expressed in gram/cut stem for that period. The water balance of the cut inflorescence was calculated by the difference in water uptake from the vase and transpiration from the inflorescence [water loss] (Li et al., 2017). 


\section{Relative fresh weight (RFW)}

The relative fresh weight of the cut inflorescences of foxtail lily was measured using the following equation:

Where, Wt is the inflorescence weight (g) at $\mathrm{t}=$ three, six or nine days during the vase-life evaluation period; W0 is the inflorescence weight $(\mathrm{g})$ at $\mathrm{t}=$ day zero (Barrs and Weatherley, 1962).

\section{Total soluble solids of petals}

Total soluble solids (TSS) in petals was measured by ABBE digital refractometer and expressed on the basis of degrees Brix ( ${ }^{\circ}$ Brix). In brief, $0.5 \mathrm{~g}$ of petals were taken and pulverized in a porcelain mortar. The obtained extract was filtered and few drops of it were poured over the glass of the refractometer. The data were recorded in light at 20 ${ }^{\circ} \mathrm{C}$ (Gebremedhin et al., 2013).

\section{Statistical analysis}

Analysis of variance (ANOVA) was performed by SAS software (version 9.1, SAS Inst., Inc., Cary, NC) and means were separated at $1 \%$ or $5 \%$ levels of probability using Fisher's least significant difference (LSD). For associations between traits and treatments, the biplot analysis was made by means of the Statgraphics centurion XVI software and two first principal components $\left(\mathrm{PC}_{1}\right.$ and $\left.\mathrm{PC}_{2}\right)$ was plotted for polygon view of the biplot and the average tester coordination. The visual correlations were estimated by using a vector view biplot existing between the traits (the cosine of the angle between their vectors).

\section{Results}

Data analysis revealed that the vase life of Foxtail flowers was significantly $(p<0.01)$ affected by different postharvest treatments (Figure 2B). All pulse treatments and preservative solutions, except preservative solution containing $120 \mathrm{mg} \mathrm{L}^{-1}$ thymol, significantly prolonged the vase life of Foxtail cut inflorescences as compared to the control treatment (Figure 2B). The longest vase-life, 13.66 days, was observed in $10 \mathrm{mg} \mathrm{L}^{-1}$ of nano-silver, followed by $15 \mathrm{mg} \mathrm{L}^{-1}$ (12.66 days) and $5 \mathrm{mg} \mathrm{L}^{-1}$ (12.33 days) of this compound. Among plant growth regulators, pulse treatment of methyl jasmonate in both concentrations was more effective in prolonging vase life compare to salicylic acid. Further, the vase life of inflorescences in a preservative solution containing $75 \mathrm{mg} \mathrm{L}^{-1}$ of menthol and thymol were higher than that in $120 \mathrm{mg} \mathrm{L}^{-1}$ of these essential oils (Figure 2B).
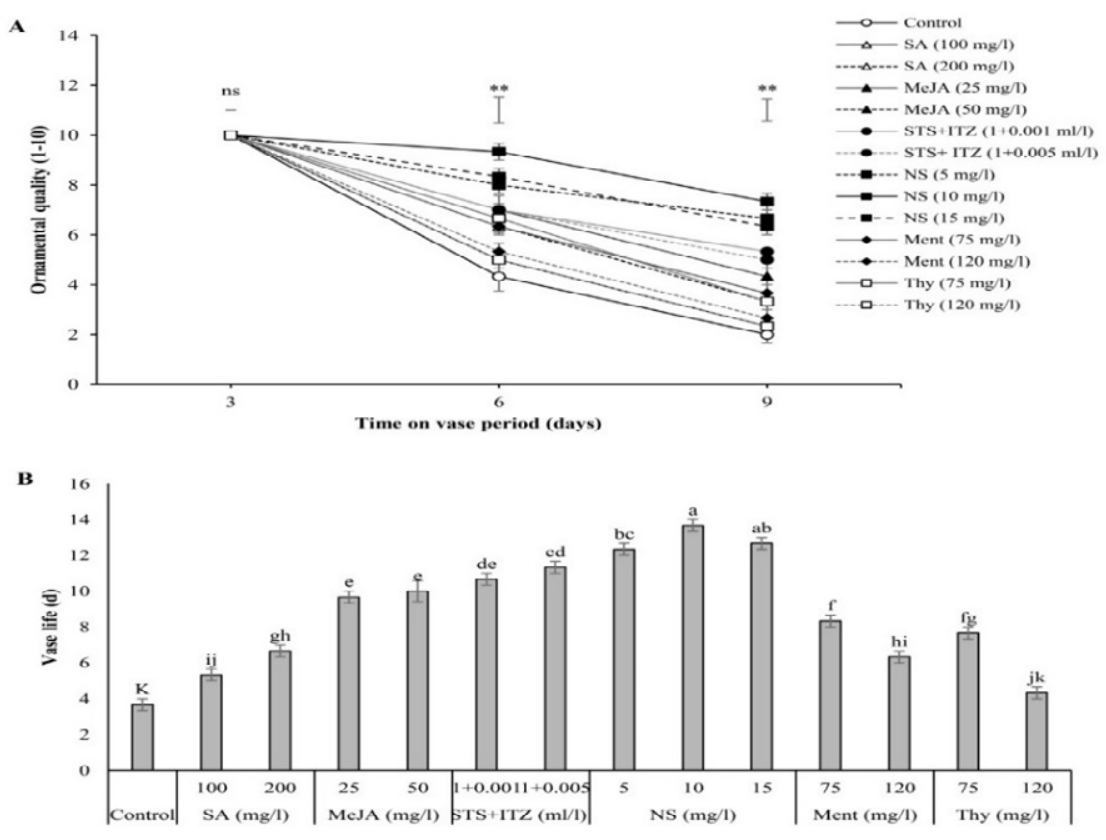

\begin{abstract}
Postharvest treatments
Figure 2. The effects of different postharvest treatments on ornamental quality (A) and vase life (B) of Eremurus cut inflorescence. Data represent the mean \pm standard error (SE). Means not sharing any letter are significantly different according to the least significant distance (LSD) test at $(p<0.05)$. ns: no significant effect; ${ }^{*}$ : significant effect at $0.01 \leq p<0.05 ; * *: p<0.01$. Bar indicated LSD value $(p<0.05)$. NS: nanosilver; STS+ITZ: silver thiosulfate+ isothiazolinone; SA: salicylic acid; MeJA: methyl jasmonate; Ment: menthol; Thy: thymol.
\end{abstract}


Appearance quality is one of the most key qualitative attributes in cut flowers which can increase their market value and acceptability. The average score of the flower's quality parameters exhibited a decreasing trend during the experiment (Figure 2A). However, the presence of preservatives in keeping solution had a significant impact on improving the apparent quality of flowers at all measured times, as compared to the solution with no preservative $(p<0.01)$. Foxtail cut flowers maintained in solution with different concentrations of nano-silver had the greatest quality scores. Following nine days of flower harvesting, the minimum quality loss was related to the concentration of $10 \mathrm{mg} \mathrm{L}^{-1}$ of nano-silver (with quality score of 8.88).
Data recorded in Figure 3 exhibited that pulse methyl jasmonate and STS+ITZ, as well as nano-silver and menthol solutions were more effective in keeping water uptake compare to control. The maximum quantity of vase solution was absorbed by NS-treated inflorescences during evaluation period. However, no significant differences were observed between salicylic acid plus thymol treatments and control during the evaluation period (Figure 3A). Similar to water uptake pattern, water loss from cut foxtail lily inflorescence significantly $(p<$ 0.01 ) varied between different postharvest treatments during the vase period (Figure 3B). In all measured dates, the highest solution loss was recorded in the flowers treated with 10 and 15 $\mathrm{mg} \mathrm{L}^{-1}$ of nano-silver, respectively, while the lowest rate was assigned to the control treatment (Figure 3B).
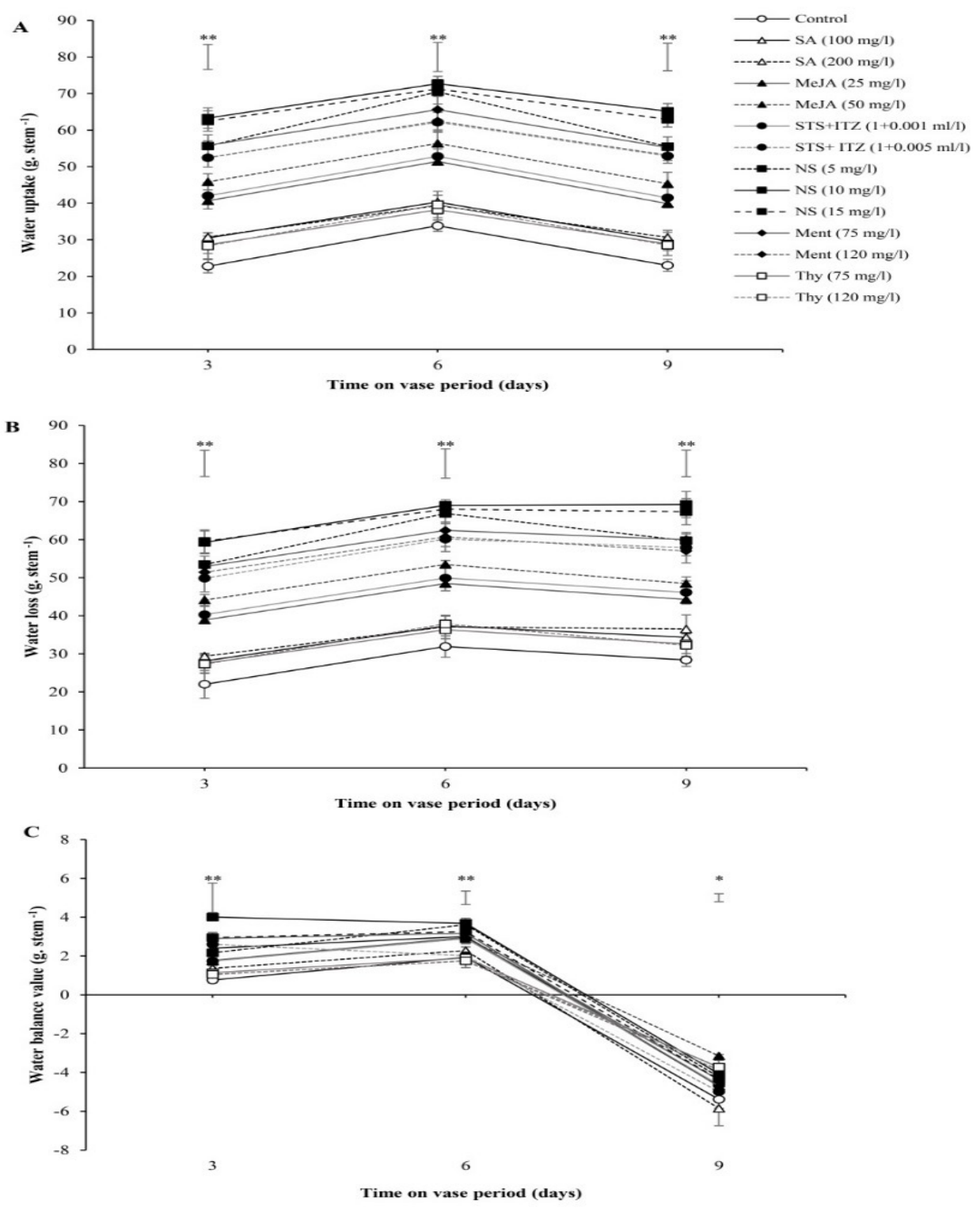

Figure 3. The effects of different postharvest treatments on water uptake (A), water loss (B), and water balance value (C) of Eremurus cut inflorescence. Data represent the mean \pm standard error (SE). ns: no significant effect; *: significant effect at $0.01 \leq p<0.05 ; * *: \mathrm{P}<0.01$. Bar indicated the least significant distance (LSD) value $(p<0.05)$. NS: nanosilver; STS+ITZ: silver thiosulfate+ isothiazolinone; SA: salicylic acid; MeJA: methyl jasmonate; Ment: menthol; Thy: thymol. 
The water balance value followed the same trend over the vase life of all treated inflorescences and the control, but data illustrated in Figure $3 \mathrm{C}$ reveal that the decline was significantly more for the control. Foxtail lily inflorescences which were treated with NS and methyl jasmonate showed better water balance compared to those with other treatments. Accordingly, the $10 \mathrm{mg}$ $\mathrm{L}^{-1} \mathrm{NS}$ treatment showed the most favorable water balance during the vase period. However, no significant differences were observed between NS treatments and methyl jasmonate, STS+ITZ, plus menthol treatments (Figure 3C).
Changes in the relative fresh weight of cut foxtail lily inflorescences exhibited similar patterns in both the control and postharvest treatments over the vase period. Data presented in Figure 4A revealed that a higher relative fresh weight was observed in florets from inflorescences placed in NS solution and pulse treatments of $100 \mathrm{mg} \mathrm{L}^{-1}$ of salicylic acid and $75 \mathrm{mg} \mathrm{L}^{-1}$ of menthol than those of control $(p<0.05)$. On the $6^{\text {th }}$ day of vas period, the maximum increase in FWP, by $45 \%$, was observed in $100 \mathrm{mg} \mathrm{L}^{-1} \mathrm{SA}$ followed by $75 \mathrm{mg} \mathrm{L}^{-1}$ of menthol $(43 \%)$. On the $9^{\text {th }}$ day of vas period, the minimum values of this attribute accompanied the control and STS+ITZ treatment, which were 83 and $81 \%$, respectively (Figure 4A).
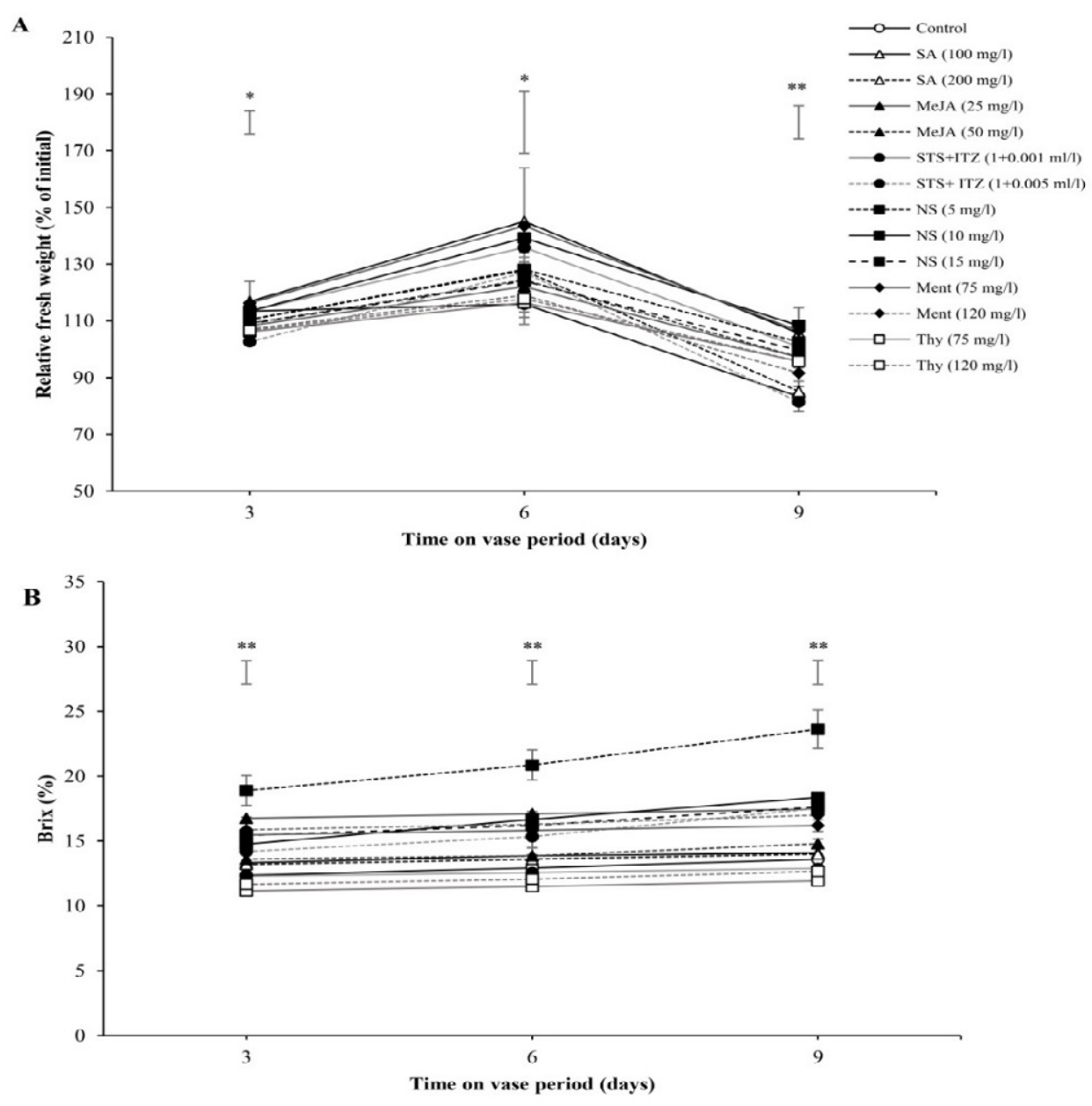

Figure 4. The effects of different postharvest treatments on relative fresh weight (A) and total soluble solid (TSS) (C) of Eremurus cut inflorescence. Data represent the mean \pm standard error (SE). ns: no significant effect; $*$ : significant effect at $0.01 \leq \mathrm{P}<0.05 ; * *$ : $\mathrm{P}<0.01$. Bar indicated least significant distance (LSD) value ( $<0.05)$.

NS: nanosilver; STS+ITZ: silver thiosulfate+ isothiazolinone; SA: salicylic acid; MeJA: methyl jasmonate; Ment: menthol; Thy: thymol.

As shown in Figure 4B, the total content of soluble solids (\% Brix) increased over the vase period. According to the results, the application of different preservatives significantly increased the TSS of flowers compared to the control treatment. During the vase period, the highest TSS in petals was obtained by application of $10 \mathrm{mg} \mathrm{L}^{-1}$ of nano-silver, while the least amount was related to thymoltreated inflorescences.

The first and second components of biplot analysis displayed 65.55 and $17.39 \%$ of the total variation, respectively (Figure 5). 


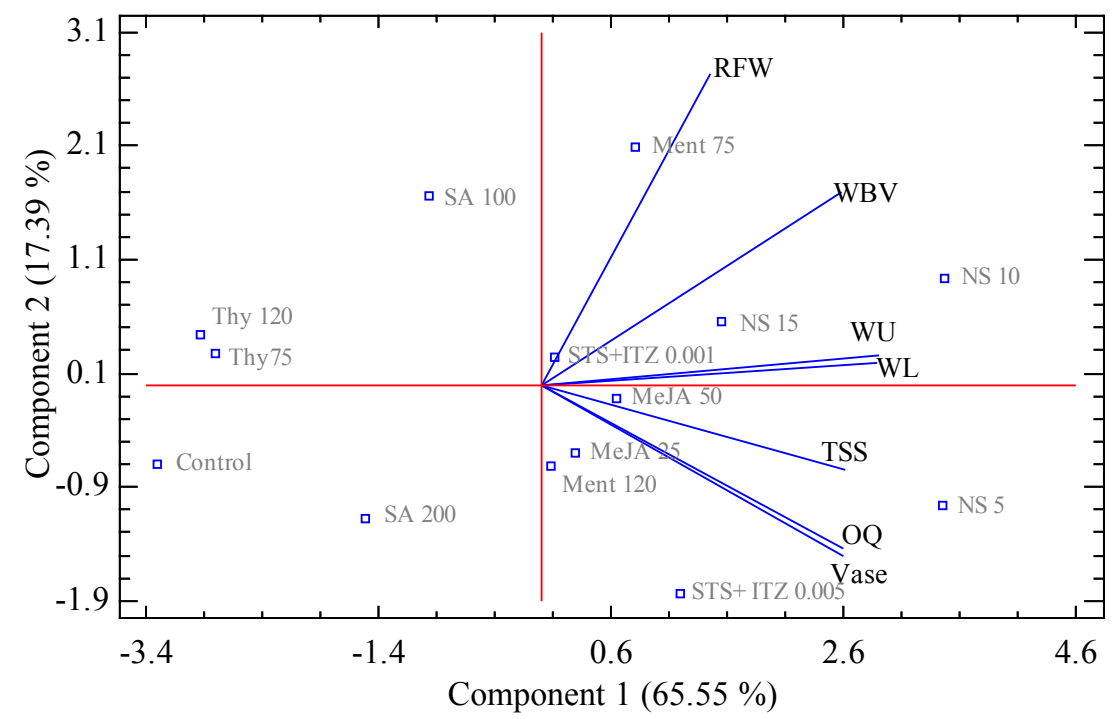

Figure 5. The treatment-by-trait (TT) biplot exhibit the traits relationships across treatment levels. The traits are the vase life (Vase), ornamental quality (OQ), water uptake (WU), water loss (WL), water balance value (WBV), relative fresh weight (RFW), and total soluble solid (TSS). NS: nanosilver; STS+ITZ: silver thiosulfate+ isothiazolinone; SA: salicylic acid; MeJA: methyl jasmonate; Ment: menthol; Thy: thymol.

The biplot figure exhibited: (1) a positive and high association (an acute angle) between the ornamental quality (OQ) plus total soluble solid (TSS) and vase life of cut inflorescence, (2) positive correlations (acute angles) between water uptake (WU) plus water loss (WL) and vase life; between the relative fresh weight (RFW) and WU plus water balance value (WBV). These relationships were highly coordinated with the numerical Pearson correlation coefficients (data not shown). The results in the biplot figure also exhibited that the cut inflorescences treated with 10 and $15 \mathrm{mg} \mathrm{L}^{-1}$ of nano-silver had high values of WU and WL, as well as WBV. Further, Foxtail lily cut inflorescences treated with $5 \mathrm{mg} \mathrm{L}^{-1}$ nano-silver and $1.0+0.005 \mathrm{ml}^{-L^{-1}}$ of STS+IZT had high values of TSS, OQ, and vase life (Figure 5).

\section{Discussion}

The vase life of cut flowers depends on various preand post-harvest factors. Reduction of carbohydrates and water uptake, vascular blockage and ethylene production can decrease cut flower vase life and accelerate their deterioration after harvesting (Van Doon, 2013; Naing and Kim, 2020). According to the results of this study, all preservative compounds and pulsing treatments significantly prolonged vase life and maintained the quality of Foxtail lily cut inflorescences during the vase period as compared with the control. The effectiveness of different treatments was varied on the prolonging vase life of cut foxtail lily inflorescences. Among the applied treatments, the most positive effect was observed in the solution containing nano-silver or silver-thiosulfate + isothiazolinone (Figure 2B).

The vase life extension was associated with enhancing the ornamental quality of the inflorescences (Figure 5). Overall, the $10 \mathrm{mg} \mathrm{L}^{-1}$ nano-silver treated cut foxtail lily inflorescences trended to have the longest vase life and best ornamental quality during the vase period. In line with these results, several previous studies have revealed that NS treatments successfully extended the longevity of various cut flowers such as gladiolus ( $\mathrm{Li}$ et al., 2017), gerbera (Liu et al., 2021), carnation (Naing et al., 2017; Park et al., 2017; Liu et al. 2018; Lin et al., 2019; Naing et al., 2021), snapdragon (Rabiza-Świder et al., 2020), peony (Zhao, 2018), and cut lisianthus (Skutnik et al., 2021). However, high levels of silver ions may cause toxicity in the flower tissues, resulting in higher ethylene production (Naing et al., 2017).

In this study, $10 \mathrm{mg} \mathrm{L}^{-1}$ of NS particles was more effective to be extended the vase life of foxtail lily as compared to 5 and $15 \mathrm{mg} \mathrm{L}^{-1}$, suggesting the application of an optimal concentration of NS particles is critical for the particular genotype. Furthermore, silver nanoparticles have been shown a strong antimicrobial property due to their small dimensions, high surface area, large external area effect, and quanta. In addition, NS particles can be attracted to microorganisms and kill them due to the lack of two electrons in their shell (Naing and Kim 2020). The silver ion of NS particles interacts and interferes with cell wall, membrane permeability, nucleic acids, and cytoplasmic components, resulting in inhibition of respiratory chain enzymes of microbes, thereby decreasing the bacterial population which may block the stems (Li et al., 2017; Park et al., 2017; Naing and Kim, 2020).

In the present study, the solution water absorbance in all treatments was higher than that of the control, with nanosilver as the top performer. Further, the biplot analysis showed that NS-treated cut inflorescences, especially with 10 and $15 \mathrm{mg} \mathrm{L}^{-1}$, had high values of WU and WBV (Figure 3 ). In agreement with these results, it has been reported that NS-treated cut flowers had high vase solution uptake and low transpiration rate (Park et al., 2017; Lin et al., 2019; 
Naing et al., 2021). Therefore, nano-silver application in vase solution through the inhibiting bacterial growth and formation of biofilm in the xylem vessels, which results in water uptake and cellular activity, and thus maintaining turbidity solution, relative fresh weight, stability of the membrane integrity, etc. during vase life of cut flowers (Naing and Kim, 2020).

Similar to nano-silver particles, isothiazolinone is considered as a well-known chemical with anti-bacterial properties that could be improved water uptake and extended the vase life of cut flowers. Furthermore, the silver ion that is released by STS has been reported to inhibit ethylene activity by replacing with copper ion in the binding site of the ethylene receptor (Celikel et al., 2010). Results of this study revealed that STS plus IZT treatment had positive effects on water relation and vase life of cut foxtail lily inflorescences. In agreement with these results, Ahmad et al. (2014) reported that the best preservative chemical was found to be isothiazolinone antimicrobial agent, which prolonged vase life by 2.2 or 1.9 days for inflorescences of 'Tap Dance' and 'Line Dance' foxtail lily cultivars, respectively, as compared to tap water (Ahmad et al., 2014).

Further, positive effects of silver thiosulfate treatment in improving water uptake, fresh weight and vase life of carnation flowers have been reported by Liu et al. (2018). However, the effectiveness of NS was more than STS on vas life of foxtail lily in the present study and on cut carnation in the previous work (Liu et al., 2018), which may be due to differences in their physical and chemical features.

It is generally accepted that flower senescence is tightly regulated by hormonal signals, and changes in plant hormone levels in flower tissues play as regulating signals for the discontinuation or commencement a of specific process. Salicylic acid is considered as a plant growth regulator that plays a key role in plant development, growth, and defense responses (Ding et al., 2002). In this study, SA treatments, especially in $200 \mathrm{mgL}^{-1}$ concentrations, significantly prolonged the vase life of cut foxtail lily inflorescences as compared to control. In agreement with these results, several previous studies reported that pre or post-harvest exogenous application of salicylic acid (SA) delayed considerably senescence and prolonged the vase life of different cut flowers such as rose, alstroemeria, and chrysanthemum (Mansouri, 2012; Kazemi et al., 2018; Langroudi et al., 2020).

Previous reports have been also demonstrated that SA has a potential role in regulating gene expression over senescence and stresses responses (Ding et al., 2002), led to prolonging in the longevity of cut flowers (Mansouri, 2012). Furthermore, published evidence supports Methyl jasmonate (MeJA) acting as a retardant agent for flower opening, resulting delayed flower senescence (Horibe and Makita, 2019). In this study, pulse treatments of MeJA in both concentrations ( 25 and $50 \mathrm{mgL}^{-1}$ ) had positive effects on water uptake and vase life of cut foxtail lily inflorescences. In line with this result, postharvest application of MeJA has been revealed to be effective in prolonging the vase life of some flowers such as cut roses (Horibe and Makita, 2019; Hasanzadeh-Naemi et al., 2021).

However, the responses of different species and cultivars of cut flowers to exogenous plant growth regulators widely varied (Horibe and Makita, 2019). In this study, MeJA treatment was more effective for prolonging the vase life of foxtail lily as compared to salicylic acid application. In agreement with these results, the effectiveness of SA and spermine was varied on prolonging of vase life of cut alstroemeria flowers (Langroudi et al., 2020). Also, in the research of Hemati et al. (2019), SA was more effective on prolonged the day to bent stem in gerbera cut flowers as compared with MeJA. Therefore, the responses of different cut flowers during vase life to a specific plant growth regulator needed to be investigating.

In this study, the use of menthol and thymol in preservative solution, especially at low concentration, had a positive effect on water relation and vase life of cut foxtail lily inflorescences. In agreement with these results, Solgi et al. (2009) revealed that thymol along with $6 \%$ sucrose had a positive impact on relative solution uptake and vase life of cut gerbera flowers.

Positive responses of the essential oils of different plants such as rosemary [Salvia Rosmarinus] (Basiri et al. 2011), menthe [Mentha spicata] (Salmi et al. 2018), savory [Satureja hortensis] (Mohammadi Kabari and Soleimandarabi, 2019), Tashenehdari [Scrophularia striata] (Mohammadi et al., 2020), Moringa [Moringa olifera] (Hassan et al., 2020), and auricula tree [Calotropis procera] (Akhtar et al., 2021) on water relation and vase life of different cut flowers were reported. Active phenolic compounds such as thymol and menthol in essential oils might damage bacterial cell walls and inhibit microbial growth, lead to a reduction of microorganism's proliferation in preservation solution. Furthermore, essential oil might delay ethylene production in cut flowers (Jitareerat et al., 2008), which need more investigation in different cut flowers.

However, the effectiveness of these compounds may be varied on various cut flowers. In this study, menthol was more effective on vase life and water uptake plus water balance value of cut foxtail lily inflorescences as compared to thymol compound, suggesting that the efficiency of various compounds of a specific essential oil may vary on prolonging the vase life of the different cut flowers.

\section{Conclusions}

The present study is the first to report the application of the different novel antimicrobial and anti-ethylene compounds as a preservative/pulsing solution to prolong postharvest longevity of cut inflorescences of domestic Eremurus spectabilis. A short vase life ( 4 days) of the foxtail lily was observed in untreated inflorescences; however, the postharvest application of preservatives/ pulsing in a solution of Foxtail lily cut flowers, in particular nano-silver, silver thiosulfate, and methyl jasmonate, markedly extended the vase life and improved water relation, which result in maintaining the appearance quality of the inflorescences during vase life period.

The findings of this study revealed that NS treatments, especially $10 \mathrm{mg} \mathrm{L}^{-1}$, could be an effective and strong antibacterial preservative to extend the vase life of cut inflorescences such as foxtail lily. Furthermore, methyl jasmonate and menthol, as an eco-friendly compound, have 
the potential to prolong the vase life of cut inflorescence of foxtail lily. However, further research is needed to investigate biochemical and physiological responses of foxtail lily to NS, methyl jasmonate, and menthol as well as optimize these treatments for commercial application in cut foxtail lily inflorescences.

\section{Author Contribution}

YB: conceptualization, data curation, formal analysis, writing original draft. NE: supervision, conceptualization, writingreview and editing, methodology, validation. MA: supervision, methodology, investigation, writing-review and editing. AN: supervision, investigation, writing - review and editing. GS: supervision, investigation, software, validation.

\section{References}

AHMAD, I.; DOLE, J.M.; SCHIAPPACASSE, F.; SALEEM, M.; MANZANO, E. Optimal postharvest handling protocols for cut 'Line Dance' and 'Tap Dance' Eremurus inflorescences. Scientia Horticulturae, v.179, p.212-220, 2014. https://doi.org/10.1016/j.scienta.2014.09.031

AKHTAR, G.; RAJWANA, I.A.; SAJJAD, Y.; SHEHZAD, M.A.; AMIN, M.; RAZZAQ, K.; ULLAH, S.; FARIED, H.N.; FAROOQ, A. Do natural leaf extracts involve regulation at physiological and biochemical levels to extend vase life of gladiolus cut flowers? Scientia Horticulturae, v.282, p.110042,2021.https://doi.org/10.1016/j.scienta.2021.110042

BASIRI, Y.; ZAREI, H.; MASHAYEKHY, K.; PAHLAVANY, M.H. Effect of Rosemary extract on vase life and some qualitative characteristics of cut Carnation flowers (Dianthus caryophyllus cv. White librity). Journal of Stored Products and Postharvest Research, v.2, n.14, p.261-265, 2011. https://doi.org/10.5897/JSPPR.9000018

BARRS, H.; WEATHERLEY, P. A re-examination of the relative turgidity technique for estimating water deficits in leaves. Australian Journal of Biological Science, v.15, p.413-428, 1962. http://dx.doi.org/10.1071/BI9620413

CELIKEL,F.G.; CEVALLOS, J.C.; REID, M.S. Temperature, ethylene and the postharvest performance of cut snapdragons (Antirrhinum majus). Scientia Horticulturae, v.125, p.429433, 2010. https://doi.org/10.1016/j.scienta.2010.04.005

DING, C.K.; WANG, C.Y.; GROSS, K.C.; SMITH, D. Jasmonate and salicylate induce the expression of pathogenesis- related-protein genes and increase resistance to chilling injury in tomato fruit. Planta, v.214, n.6, p.895901, 2002. https://doi.org/10.1007/s00425-001-0698-9

GEBREMEDHIN, H.; TESFAYE, B.; MOHAMMAD, A.; TESGAY, D. Influence of preservative solutions on vase life and postharvest characteristics of (Rosa hybrida) cut flowers. International Journal for Biotechnology and Molecular Biology Research, v.4, p.111-118, 2013. https://doi.org/10.5897/IJBMBR2013.0171
HADIZADEH, H.; BAHRI, B.A.; QI, P.; WILDE, H.D.; DEVOS, K.M. Intra-and interspecific structure. Horticulture Research, v.7, p.1-13, 2020. https://doi. org/10.1038/s41438-020-0265-9

HASANZADEH-NAEMI, M.; ZARINNIA, V.; JARI, S.K.; FATEHI, F. The effect of exogenous methyl jasmonate and brassinosteroid on physicochemical traits, vase life, and gray mold disease of cut Rose (Rosa hybrida L.) flowers. Journal of the Saudi Society of Agricultural Sciences, In Press, 2021. https://doi.org/10.1016/j.jssas.2021.05.007

HASSAN, F.A.S.; MAZROU, R.; GABER, A.; HASSAN, M.M. Moringa extract preserved the vase life of cut roses through maintaining water relations and enhancing antioxidant machinery. Postharvest Biology and Technology, v.164, p.111156, 2020. https://doi. org/10.1016/j.postharvbio.2020.111156

HEMATI, E.; DANESHVAR, M.H.; HEIDARI, M. The roles of sodium nitroprusside, salicylic acid, and methyl jasmonate as hold solutions on vase life of Gerbera jamesonii 'Sun Spot'. Advances in Horticultural Science, v.33, p.187-195, 2019. https://doi.org/10.13128/ahs-24261

HORIBE, T.; MAKITA, M. Methyl jasmonate treatment delays flower opening and petal wilting of three cut rose cultivars. Journal of Horticultural Research, v.27. p.110, 2019. https://doi.org/10.2478/johr-2019-0016

JITAREERAT, P.; RUENROENGKLIN, N.; UTHAIRATANAKIJ, A.; WONGSAREE, C. Use of herbal extracts for inhibiting microbial growth in holding solutions of cut rose. Acta Horticulturae, v.804, p.291-295, 2008. https://doi.org/10.17660/ActaHortic.2008.804.40

KAZEMI, M.; AMERI, A. Response of vase-life carnation cut flower to salicylic acid, silver nanoparticles, glutamine and essential oil. Asian Journal of Animal Science, v.6, p.122-131, 2012. https://doi.org/ 10.3923/ajas.2012.122.131

KAZEMI, M.; ABDOSSI, V.; KALATEH JARI, S.; LADAN MOGHADAM, A.R. Effect of pre-and postharvest salicylic acid treatment on physio-chemical attributes in relation to the vase life of cut rose flowers. The Journal of Horticultural Science and Biotechnology, v.93, p.81-90, 2018. https://doi.org/10.1080/14620316.2017.1344571

LANGROUDI, M.E.; HASHEMABADI, D.; KALATEJARI, S.; ASADPOUR, L. Effects of silver nanoparticles, chemical treatments and herbal essential oils on the vase life of cut alstroemeria (Alstroemeria 'Summer Sky') flowers. The Journal of Horticultural Science and Biotechnology, v.95, p.175-182, 2020. https://doi.org/10.1080/14620316.2019.1657786

LI, H.; LI, H.; LIU, J.; LUO, Z.; JOYCE, D.; HE, S. Nanosilver treatments reduced bacterial colonization and biofilm formation at the stem-ends of cut gladiolus 'Eerde' spikes. Postharvest Biology and Technology, v.123, p.102-111, 2017. https://doi.org/10.1016/j.postharvbio.2016.08.014 
LIN, X.; LI, H.; LIN, S.; XU, M.; LIU, J.; LI, Y.; HE S. Improving the postharvest performance of cut spray carnations by vase treatments with nano silver and sucrose. The Journal of Horticultural Science and Biotechnology, v.94, p.513-521, 2019. https://doi.org/10.1080/14620316.2 019.1572461 .

LIU, J.; LAI, L.; LIU, H.; LI, H.; YU, G.; SUN, Y.; HE, S. Nano-silver treatment reduces bacterial proliferation and stem bending in cut gerbera flowers: An in vitro and in vivo evaluation. Postharvest Biology and Technology, v.180, p.111595, 2021. https://doi.org/10.1016/j. postharvbio.2021.111595

LIU, J.; ZHANG, Z.; LI, H.; LIN, X.; LIN, S.; JOYCE, D.C.; HE, S. Alleviation of effects of exogenous ethylene on cut 'Master' carnation flowers with nano-silver and silver thiosulfate. Postharvest Biology and Technology, v.143, p.86-91, 2018. https://doi.org/10.1016/j. postharvbio.2018.04.014

MANSOURI, H. Salicylic acid and sodium nitroprusside improve postharvest life of chrysanthemums. Scientia Horticulturae, v.145, p.29-33, 2012. https://doi. org/10.1016/j.scienta.2012.07.016

MOHAMMADI, M.; AELAEI, M.; SAIDI, M. Antibacterial properties of Scrophularia striata Boiss. (Tashenehdari) extract on vase life improvement in" Stanza" and" Pink Elegance" gerbera cut flowers. Biocatalysis and Agricultural Biotechnology, v.28, p.101738, 2020. https://doi.org/10.1016/j.bcab.2020.101738

MOHAMMADI KABARI, S.F.; SOLEIMANDARABI, M.J. Improving Alstroemeria vase life by plant extracts and 8-hydroxyquinoline sulfate. Propagation of Ornamental Plants, v.9, p.1-11, 2019.

NAING, A.H.; KIM, C.K. Application of nano-silver particles to control the postharvest biology of cut flowers: A review. Scientia Horticulturae, v.270, p.109463, 2020. https://doi.org/10.1016/j.scienta.2020.109463

NAING, A.H.; WIN, N.M.; HAN, J.S.; LIM, K.B.; KIM, C.K. Role of nano-silver and bacterial strain Enterobacter cloacae in increasing vase life of cut carnation 'Omea'. Frontiers in Plant Science, v.8 p.1590, 2017. https://doi. org/10.3389/fpls.2017.01590

NAING, A.H.; SOE, M.T.; KYU, S.Y.; KIM, C.K. Nanosilver controls transcriptional regulation of ethylene-and senescence-associated genes during senescence in cut carnations. Scientia Horticulturae, v.287, p.110280, 2021. https://doi.org/10.1016/j.scienta.2021.110280
PARK, D.Y.; NAING, A.H.; AI, T.N.; HAN, J.; KANG, I.K.; KIM, C.K. Synergistic effect of nano silver with sucrose on extending vase life of the carnation cv. Edun. Frontiers in Plant Science, v.8, p.1601, 2017. https://doi. org/10.3389/fpls.2017.01601

RABIZA-ŚWIDER, J.; SKUTNIK, E.; JĘDRZEJUK, A.; ROCHALA-WOJCIECHOWSKA, J. Nanosilver and sucrose delay the senescence of cut snapdragon flowers. Postharvest Biology and Technology, v.165, p.111165, 2020. 10.1016/j.postharvbio.2020.111165

SALMI, M.S.; HOSEINI, M.F.; HEIDARI, M.; DANESHVAR, M.H. Extending vase life of cut rose (Rosa hybrida L.) cv. Bacara by essential oils. Advances in Horticultural Science, v.32, p.61-69, 2018.

SCHIAPPACASSE, F.; SZIGETI, J.C.; MANZANO, E.; KAMENETSKY, R. Eremurus as a new cut flower crop in Aysen, Chile: introduction from the northern hemisphere. Acta Horticulturae, v.1002, p.115-122, 2013. https://doi. org/10.17660/ActaHortic.2013.1002.13

SKUTNIK, E.; LUKASZEWSKA, A.; RABIZA'SWIDER, J. Effects of postharvest treatments with nanosilver on senescence of cut lisianthus (Eustoma grandiflorum (Raf.) Shinn.) flowers. Agronomy, v.11, p.215, 2021. https://doi.org/ 10.3390/agronomy11020215

SOLGI, M.; KAFI, M.; TAGHAVI, T.S.; NADERI, R. Essential oils and silver nanoparticles (SNP) as novel agents to extend vase-life of gerbera (Gerbera jamesonii cv 'Dune') flowers. Postharvest Biology and Technology, v.53, p.155-158, 2009. https://doi.org/10.1016/j. postharvbio.2009.04.003

VAN DOORN, W.G. Water relations of cut flowers: an update. Horticultural Reviews, v.40, p.55-106, 2013. https://doi.org/10.1002/9781118351871

WANG, C.; FANG, H.; GONG, T.; ZHANG, J.; NIU, L.; HUANG, D.; HUO, J.; LIAO, W. Hydrogen gas alleviates postharvest senescence of cut rose 'Movie Star' by antagonizing ethylene. Plant Molecular Biology, v.102, p.271-285, 2020. https://doi.org/10.1007/s11103-01900946-3

ZHAO. D. Nano-silver modifies the vase life of cut herbaceous peony (Paeonia lactiflora Pall.) flowers. Protoplasma, v.255, p.1001-1013, 2018. https://doi. org/10.1007/s00709-018-1209-1. 